\title{
The Implementation of Indonesian Cross-Major Program in The Structuration and Structural Functional Perspective
}

\author{
Shofia Darun Nasifah, Universitas Negeri Malang, shofiadn09@gmail.com, ORCID:0000-0002-2253-6733 \\ Joan Hesti Gita Purwasih, Universitas Negeri Malang, joan.hesti.fis@um.ac.id, ORCID: 0000-0002-0085- \\ 7974
}

\begin{abstract}
The author portrayed the reality of cross-major application in Indonesia. The objectives of research were to explain the reality of cross-major implementation and to describe students' perception on the cross-major implementation. This research employed mixed methods with sequential exploratory model. Data analysis was conducted using structuration and structural functional theories. The result of research showed that cross-major program is a policy that cannot be implemented perfectly corresponding to the enacted rule. Students were not given discretion to choose the subject they are interested in. there were two factors causing such the condition: classroom availability and teacher availability. An ideal cross-major based on students' pure wish was highly avoided because it would be hazardous to the composition of students in each of classes and would lead to the obstacle in subject scheduling. Therefore, the school developed system reengineering to make the program as if compatible to the enacted regulation.
\end{abstract}

Keywords: Curriculum, Cross-major, Structural functional, School Received: $15.11 .2020 \quad$ Accepted: 13.12.2020 $\quad$ Published: 17.01.2021

\section{INTRODUCTION}

Education is each of individuals' fundamental need in undertaking life within society. Through education, an individual can explore him/her self to be a smart, skilful, and dignified person. Education as a way to national development creates the feeling of responsibility for achieving national objective, social and individual rights (Ahmad et al., 2014). Education is a parameter of a nation's advance determined by the quality of human resources, teachers and students. If the quality of education is good, a nation will be a developed one. Otherwise, if the quality of education is bad, it will impact on a nation's incapability of competing with other nations (Khotimah, 2019).

A state's successful education can be seen from the curriculum enacted. Curriculum is defined as guidelines in a set of plans and regulations concerning objective and content as thee basis of learning activity organization (Melmambessy, 2017). Curriculum in Indonesia has been changed considerably from Rencana Pelajaran (Lesson Plan) of 1947, Curriculum of 1952, Curriculum of 1964, Curriculum of 1968, Curriculum of 1975/1976, Curriculum of 1984, Curriculum of 1994, Competence-Based Curriculum of 2004, Education Unit Level Curriculum of 2006 to Curriculum of 2013 (Riafadilah \& Dewi, 2018). The change of curriculum needs to be made in order to be in line with time development (Mulyasa, 2013) and to solve global problem to keep surviving (Oliva \& Gordon, 2013).

The curriculum enacted in Indonesia currently is Curriculum of 2013. This curriculum aims: (1) to balance soft skill and hard skill through developing students' attitude (affective), knowledge (cognitive) and skill (psychomotor) aspects (Azka, 2015), (2) to prepare the creative, innovative, productive, and affective next generation (Machali, 2014), (3) to encourage the students to acquire theoretical knowledge, to think critically, and to participate in looking for a solution to the phenomenon within society through life-based learning (Widianto et al., 2020). To achieve those objectives, curriculum contains subject structure to be taken by students in the learning activity. It is called the curriculum structure. The curriculum structure in Senior High School (SMA) consists of general content, academic concentration content, and academic cross-major content (Undang-Undang Republik Indonesia Nomor 20 Tahun 2003 Tentang Sistem Pendidikan Nasional [Republic of Indonesia's Law Number 20 of 2003 about National Education System], n.d.). Although the national education standard has been legitimized since 2003, the implementation of academic cross-major content has been just confirmed actually in the curriculum of 2013. The curriculum of 2013 requires the implementation of major and cross-major obligatorily to give the students an opportunity of developing competency according to interest, talent, and/or academic ability in a certain group of subjects (Peraturan Menteri Pendidikan Dan Kebudayaan Republik Indonesia Nomor 64 Tahun 2014 Tentang Peminatan Pada Pendidikan Menengah [Republic of Indonesia's Minister 
of Education and Culture Number 64 of 2014 about Majoring in Secondary Education], n.d.). This regulation applies to all Senior High Schools in Indonesian areas.

However, the regulation, in fact, cannot be actually applied to schools. In this case, the author sees the reality in Malang City called an Education City (Burhanudin, 2016). This predicate is given because many schools and universities (Permana, 2016) can be the agent of changes and the model of education organization to other regions. Nevertheless, this condition in fact cannot really ensure the implementation of education quality corresponding to Government's direction. Some Senior High Schools in Malang City are considered as incapable of organizing education corresponding to the rule of 2013 Curriculum, one of which is SMAN 9 Malang.

Considering the result of pre observation and interview, some problems are found in which the cross-major subject selection system is not determined based on students' but schools' interest. Interest (major) is defined as the feeling of being interested in something or activity volitionally and without compulsion (Slameto, 2010). Therefore, cross-major subject is optional in nature chosen deliberately by students based on their interest and parents or counselor's direction (Musdar, 2015). It is important as it can be a bridge for students in learning other subjects to support the job field they will choose later (Nugroho \& Prishardoyo, 2017). If the determination is inappropriate, it will result in learning difficulty and failure (Auliani et al., 2017). This practice is different from Government's regulation in which, crossmajor program should aim to accommodate students' interest, talent, and/or academic ability in choosing subject beyond the major group (Direktorat Jenderal Pendidikan Dasar dan Menengah Kementerian Pendidikan dan Kebudayaan, 2017).

The similar problem occurs in some other schools: (1) (1) SMAN 6 Semarang, the selection of crossmajor subjects is determined by school, thereby making the students less motivated in attending the learning because it is not compatible to their interest and results in hard learning burden (Dewi, 2016). (2) SMAN 1 Seririt of Buleleng Regency, the selection of cross-major subjects is determined by school encouraging the learning management to be made equal regardless the students' characteristics and interest (Widiawati, 2019). (3) SMAN 1 Sungai Ambawang of Kuburaya Regency, the limitation of students' right in choosing the subject compatible to their interest (Wahyudi et al., 2018). (4) SMAN 1 Bulukamba of Brebes Regency, students feel being compelled by the teachers to attend certain subject incompatible to their interest (Noer, 2016). Meanwhile, some Senior High Schools (SMAs) and Islamic Senior High Schools (MAs) in Lembang Sub District do not give the students an opportunity of choosing subject according to their interest (Riafadilah \& Dewi, 2018).

Considering the problems, this research aims to explain the implementation of cross-major in school using qualitative method. Furthermore, this research shows students' perception on the implementation of cross-major in school through quantitative method. The implementation of program is related to the process containing regulation, rationale, and mechanism of activity. Meanwhile, perception relates to an individual activity process in giving impression, assessment, or opinion by interpreting something based on information acquired (Chairunnisa, 2011). Perception is also defined as an individual's process of choosing, governing, and interpreting information to create a meaningful comprehensive idea (Kotler, 2000). Perception is affected by self, environment, and culture (Toha, 2003).

These two problems are raised for the following reasons: (1) confronting two different sides: schools and students' point of views on the cross-major implementation, (2) using qualitative and quantitative approach to obtain comprehensive data supporting each other, (3) the result of research was analyzed in two theoretical perspectives: Anthony Giddens' structuration theory to show the relationship between structure and agent as well as Talcott Parsons' structural functional theory to show the process of implementing social system through AGIL scheme (Adaptation, Goal attainment, Integration, Latency). These three points are difference and novelty of this study all at once, compared with previous studies.

\section{METHODS}

This mixed method used sequential exploratory type of research, combining qualitative and quantitative approach to obtain more comprehensive, valid, reliable, and objective data conducted in two successive phases (Creswell, 2015). In the first phase, qualitative approach was used to explore in-depth the crossmajor implementation involving: rule enacted, factor considered, and implementation mechanism. Data was collected through observation, interview, and documentation. The informants of research were selected using purposive sampling technique, consisting of headmasters, deputies of headmaster for curriculum, cross-major teachers, and cross-major students. Data was analyzed in three stages: data reduction, data display, and conclusion drawing (Sugiyono, 2011). Data validation was carried out using source and method triangulation to make the data of research actually valid and accountable for. Source triangulation was conducted by comparing data from different sources using the same method, while 
method triangulation by comparing data coming from the same source using different method (Moleong, 2016).

Furthermore, in the second phase, the result of qualitative data was used to underlie the development of research instrument in quantitative approach. Quantitative approach is used to describe the students' perception on the cross-major implementation. The number of population was 1,105 respondents with the sample $10 \%$ of population number, 111 respondents. The sample was taken using proportionate stratified random sampling, conducted randomly by considering certain stratum (Singarimbun \& Effendi, 2006).

The stratum intended is students' grade level: $10^{\text {th }}, 11^{\text {th }}$, and $12^{\text {th }}$. The instrument of research is a questionnaire containing single variable with three indicators: knowledge, expectation, and assessment, consisting of 21 statement items. The questionnaire organized in the form of Likert Scale interval data with the following scoring guidelines: Very Agree (score 4), Agree (score 3), Disagree (score 2) and Very Disagree (score 1). The questionnaire was trialed with 30 respondents with the score result of $r_{\text {stat }}>0.361$ ( $\mathrm{r}_{\text {table}}$ ) and reliable with score of 0.878 indicating very strong reliability. Questionnaire is distributed to 111 respondents, the responses of which were then processed using SPSS version 24.0 application in three stages: editing, coding, and tabulating. Data was analyzed using descriptive univariate analysis of percentage. Although this research integrated two approaches, the analysis used qualitative data more dominantly, while quantitative data was used as secondary and supporting one.

\section{RESULTS}

\section{The Gap between Policy and Cross-Major Implementation in School}

Cross-major is one of compulsory programs in Indonesian Curriculum of 2013. This program, according to Republic of Indonesia Minister of Education and Culture's Regulation Number 64 of 2014, is provided to support the expansion of students' interest, talent, and capability choices leading to the mastery of scholarly subject group beyond their academic major group. Overall, this rule mandates the following policy.

1. Each student in all educational units is entitled to get education service according to his/her talent, interest, and capability.

2. Students can choose cross-major subject although the subject comes from the major group not existing in the school.

3. The students can choose 2 cross-major subjects for the $10^{\text {th }}$ grade and 1 cross-major subject for $11^{\text {th }}$ and $12^{\text {th }}$ grades.

4. Students can choose 3 cross-major subjects, if in the major group, students choose three subjects. However, in practice there is an incompatibility of cross-major implementation in school to the Curriculum of 2013 (K13). Such condition persists until today. The incompatibility can be seen in the table 1.

Table 1. Finding matrix of incompatibility of cross-major program implementation to the guidelines of 2013 curriculum

\begin{tabular}{|c|c|c|c|c|}
\hline \multirow[t]{2}{*}{ No } & \multirow[t]{2}{*}{ Aspect } & \multicolumn{2}{|l|}{ Cross-Major Program } & \multirow[t]{2}{*}{ Conclusion } \\
\hline & & At school & Guidelines of K13 & \\
\hline 1 & $\begin{array}{l}\text { Subject } \\
\text { Selection } \\
\text { System }\end{array}$ & $\begin{array}{l}\text { a. In } 2014 \text { (the school began to } \\
\text { implement cross-major } \\
\text { program for the first time) the } \\
\text { school decides the students' } \\
\text { cross-major subject. } \\
\text { b. In 2015, the cross-major } \\
\text { subject is decided based the } \\
\text { largest votes in the class }\end{array}$ & $\begin{array}{l}\text { Students are given discretion } \\
\text { of choosing the subject } \\
\text { according to their own } \\
\text { interest }\end{array}$ & incompatible \\
\hline 2 & $\begin{array}{l}\text { Class/Learn } \\
\text { ing Room } \\
\text { System }\end{array}$ & $\begin{array}{l}\text { Students keep sitting down in the } \\
\text { class according to their grade } \\
\text { level. }\end{array}$ & $\begin{array}{l}\text { Students move to another } \\
\text { class according to the subject } \\
\text { they are interested in. }\end{array}$ & incompatible \\
\hline 3 & $\begin{array}{l}\text { Subject } \\
\text { Provided }\end{array}$ & $\begin{array}{l}\text { Economics, Geography, Sociology, } \\
\text { Physics, Biology, English Letters, } \\
\text { Japanese, and German }\end{array}$ & $\begin{array}{l}\text { School can provide all subjects } \\
\text { in which the students are } \\
\text { interested }\end{array}$ & Incompatible \\
\hline
\end{tabular}

Such the incompatibility is due to four factors: teacher availability, classroom availability, even distribution of student number, and scheduling easiness. 
Firstly, teacher availability is related to the fulfillment of teachers' workload, i.e. holding at least 24-hour to 40 face-to-face learning conducted in administrative unit, the base of which is corresponding to Government Regulation Number 74 of 2008. It means the opening of cross-major class is made a means of fulfilling the teachers' need for teaching hour, adjusted with their specialty study field. Secondly, classroom availability has an impact on the number of cross-major classes opened and cross-major subject provided. Thirdly, the even distribution of student number relates to the requirement of minimally 20 students and maximally 36 students in one class for Senior High School level, according to Republic of Indonesia Minister of Education and Culture's Regulation Number 17 of 2017. It is intended to prevent the gap from occurring between one class and another, so that the learning can run effectively. Fourthly, the scheduling easiness relates to class moving system. The students move to another class in each of subject turn. The decision of cross-major subject made by school is considered as easier, more effective, and efficient in scheduling compared with the one made purely based on interest, because the latter requires the students with the same interest to assemble in one same class.

In fact, those four factors still become the basic cause of gap in cross-major implementation in some schools in Indonesia, particularly in human resource elements. It can be seen from a previous study conducted in SMAN 1 Sungai Ambawang finding limited number of teaching staffs and infrastructure (Wahyudi et al., 2018). Similarly, SMAN 1 Lembang and MA Al-Amanah Lembang lacked of teachers in certain subject (Riafadilah \& Dewi, 2018). Meanwhile, SMAN 1 Sungai Bulukamba should fulfill the lack of teaching hour for the certified teacher and found difficulty in accessing the learning sources (Noer, 2016).

\section{System Reengineering: Cross-Major Implementation in Structuration and Structural Functional Integration}

When the government decided the change of curriculum, schools are on the executor of policy position. Therefore, schools should be subjected to the rule and attempt to accommodate the new policy. Schools should reengineer their internal system due to limited infrastructure and teacher resource. Such condition indicates that the top-down change of policy leads the structure in lower layer to conduct a series of adaptations. For that reason, the author analyzes the condition using structuration theory (Anthony Giddens) and structural functional (Talcott Parsons). The framework of analysis the author used is illustrated in the figure 1.

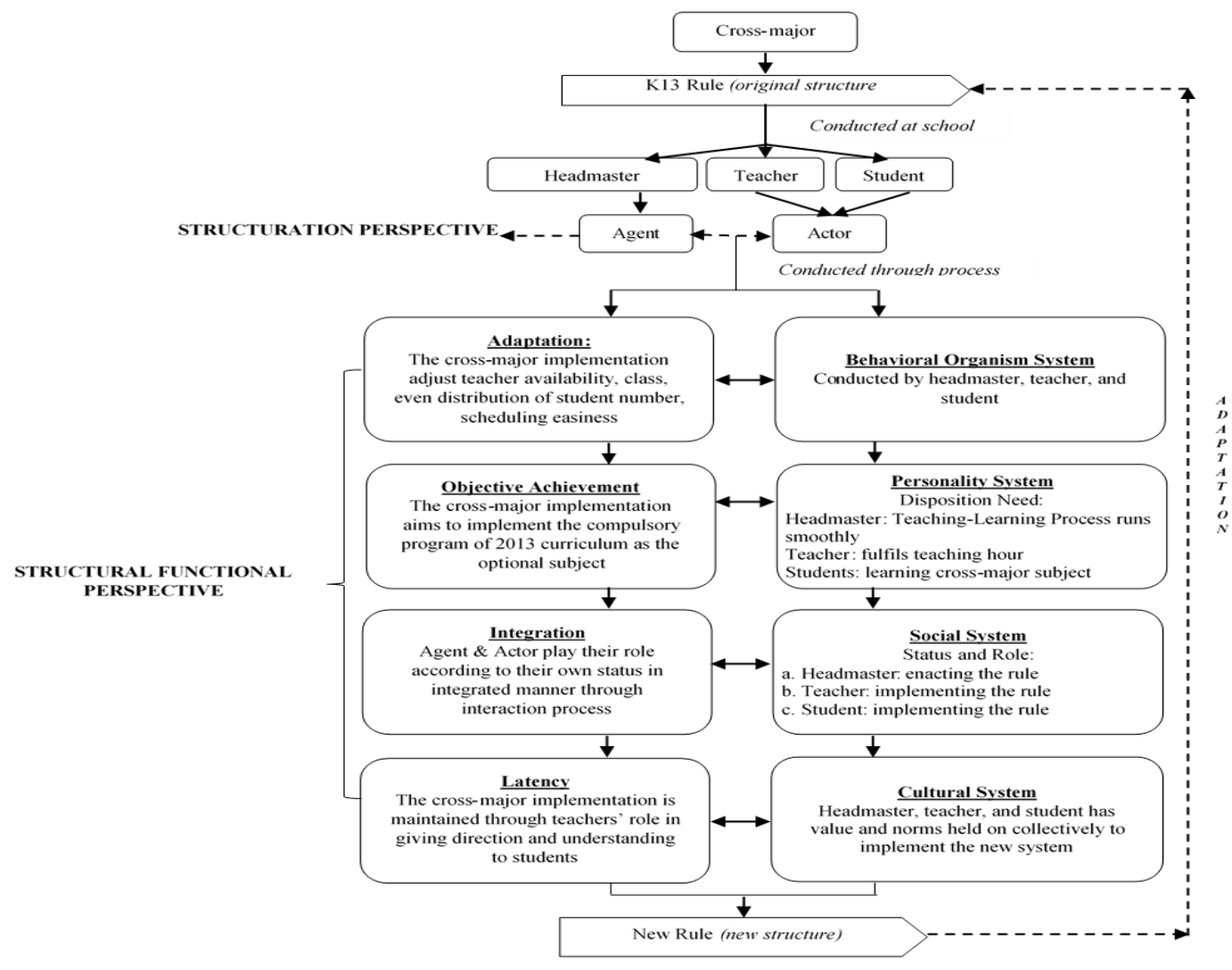

Figure 1. Framework of cross-major implementation in structuration and structural functional perspectives 
The result of research shows that a structure alone cannot perform well; there are always agent and actor involved within it. In this context, headmaster occupies the highest position in social structure. $\mathrm{He} / \mathrm{she}$ is authorized to enact rule and social control over those under him/her. Headmaster is an "agent" because his/her role is inherent to the ownership of rule (Kinseng, 2017). Meanwhile, teacher and student occupy the position under the headmaster. The position makes them obligatorily obeying the rule enacted by the superior. Teacher and student are "actors" taken action only according to the scenario written for them (Giddens, 1993). Therefore, actor's action is always affected by value and norm governing $t$ their action. It indicates that there is an agent's domination over actor in a social system.

An agent and an actor have ability of changing and maintaining the existing condition. The ability is realized through certain strategy to undertake the structure in order to create equilibrium in social system (Ritzer \& Goodman, 2008). The strategy is taken through the process of fulfilling four basic functions: Adaptation, Goal Attainment, Integration, Latency (AGIL) with four action systems: behavioral organism, personality, social, and cultural (Talcott Parsons \& Mayhew, 1982).

Firstly, adaption function. A system should adapt to environment and need. It is conducted through behavioral organism action system by agent and actor, in this case headmaster, teacher, and student. Originally, this condition is, of course, not easy for the school to accommodate the cross-major policy. In this condition, the agent then attempts to develop strategy by considering a variety of resources owned. In this condition, the school adapts by considering the factors of teacher availability, classroom availability, student number, and scheduling process. Furthermore, the strategy is developed. The role of headmaster as agent is very important because the strategy becoming the school's policy is under his/her responsibility. However, the condition will not be achieved without support from teachers at school.

Secondly, objective achievement function. A system should have clear objective and attempt to achieve the objective. It is accomplished by agent and actor, through personality action system, having disposition need and mobilizing the resource to achieve it. Disposition need is individual need arising in certain social setting. Headmaster needs to implement the Teaching-Learning Activity (KBM) well, teacher needs to fulfill the inadequate teaching hour, and student needs to learn other subjects beyond the majoring group. These three disposition needs can be fulfilled through one shared objective, the cross-major implementation.

In this case, the author finds that the change of system is not a recommendation emphasized on primarily. Building system is important, but building human resource is much more important. Teacher is an agent of education. Therefore, teacher quality should be improved. Measuring work quality through substantial teaching hour workload cannot be justified completely. In this case, cross-major policy instead collides with the policy of teachers' minimum compulsory teaching hour. This condition indicates that the government, in formulating a policy, seems pay no attention to overlapping policy and actual condition. As a result, the achievement of teachers' objective becomes main consideration rather than the objective of meeting the students' interest.

Thirdly, integration function. A system should be able to organize the relationship between its elements by controlling the agent-actor relation through social action system. It can be seen from the presence of interaction between headmaster, teacher, and student based on its status and roles integrated with each other through socialization and internalization process. In the process, teacher's role in giving understanding to students is very important. The process can also be a means of meeting the need through students' self binding to system social. It is indicated through the compliance with the rule enacted to make the cross-major implementation running well and smoothly.

Fourthly, pattern maintaining function. A system should be able to maintain value and norm as collective consciousness manifested into cross-major rule at school. The schools act as if the students choose themselves their cross-major class. They conduct survey on students' interest. However, finally the students are directed to choose the cross-major subject based on the class agreement. The rule is maintained through cultural action system conducted through teachers' reinforcement to students. Teachers attempt to make the students interested in the subject they are not interested in originally. They expect that students will accept and follow later the policy specified. If teachers fail in creating students' learning circumstance and learning outcome, of course the conflict will occur. Students are considered as failed in fulfilling the provision of minimum learning outcome limit and teachers also considered as failed in making the students understanding the material well.

The enactment of cross-major rule in the school results in a new social structure as the result of the modification of original (given) social structure. On the one hand, the rule serves to organize, to restrain, and to determine the actor's behavior. On the other hand, the rule serves to enable the agent and actor to implement cross-major program well and to meet the disposition needs (Nirzalin, 2013). Meanwhile, an attempt of maintaining the existing condition is indicated with the successful implementation of crossmajor rule by the school for about six years. It indicates that education play a big role in establishing 
structure within society in global era (Maunah, 2016). Social structure can be established to meet certain need or objective, thereby functioning in constructing society culture (Turner et al., 2010). Structure is obtained from the result of collective social construction developed deliberately, reproduced, transformed, and maintained by agent and actor that is restraining and enabling in nature (Kinseng, 2017).

\section{Integration Actor Views Structure: Students' Perception on Cross-Major Implementation}

How actor views structure is manifested into students' perception on the cross-major implementation measured using 3 indicators: knowledge, expectation, assessment. The indicator of knowledge aims to represent the students' assessment on the compatibility of cross-major implementation at school to the rule of 2013 Curriculum. Each of indicators is divided into two categories: rule and resource in cross-major implementation. The result of calculation on the responses deriving from 111 respondents can be seen in the table 2 .

Table 2. Result of calculation on respondents' responses

\begin{tabular}{|c|c|c|c|c|c|c|c|}
\hline \multirow{3}{*}{$\begin{array}{l}\text { Indicator of } \\
\text { Research }\end{array}$} & \multicolumn{7}{|c|}{ Percentage of Respondents' Response } \\
\hline & \multicolumn{3}{|l|}{ Rule } & \multicolumn{4}{|c|}{ Consideration } \\
\hline & $\begin{array}{l}\text { Subject } \\
\text { Determini } \\
\text { ng System }\end{array}$ & $\begin{array}{l}\text { No. of } \\
\text { Subject } \\
\text { Attended }\end{array}$ & $\begin{array}{l}\text { Learnin } \\
\text { g Load } \\
\text { Assume } \\
\text { d }\end{array}$ & $\begin{array}{l}\text { Teacher } \\
\text { Availabilit } \\
\text { y }\end{array}$ & $\begin{array}{l}\text { Class } \\
\text { availabili } \\
\text { ty }\end{array}$ & $\begin{array}{l}\text { Even } \\
\text { Distribu } \\
\text { tion of } \\
\text { Student } \\
\text { Number }\end{array}$ & $\begin{array}{l}\text { Subject } \\
\text { Scheduli } \\
\text { ng }\end{array}$ \\
\hline Knowledge & $\begin{array}{l}55 \% \\
\text { knowing } \\
\text { very much }\end{array}$ & $\begin{array}{l}60.4 \% \\
\text { knowing } \\
\text { very much }\end{array}$ & $\begin{array}{l}54.1 \% \\
\text { knowing } \\
\text { very } \\
\text { much }\end{array}$ & $\begin{array}{l}63.1 \% \\
\text { knowing } \\
\text { enough }\end{array}$ & $\begin{array}{l}53.2 \% \\
\text { knowing } \\
\text { enough }\end{array}$ & $\begin{array}{l}53.2 \% \\
\text { knowing } \\
\text { enough }\end{array}$ & $\begin{array}{l}61.3 \% \\
\text { knowing } \\
\text { enough }\end{array}$ \\
\hline Expectation & $\begin{array}{l}48.6 \% \\
\text { expecting } \\
\text { enough } \\
\text { correspon } \\
\text { ding to K13 }\end{array}$ & $\begin{array}{l}45.9 \% \\
\text { expecting } \\
\text { enough } \\
\text { correspon } \\
\text { ding to } \\
\text { K13 }\end{array}$ & $\begin{array}{l}55.9 \% \\
\text { expectin } \\
\text { g enough } \\
\text { correspo } \\
\text { nding to } \\
\text { K13 }\end{array}$ & $\begin{array}{l}57.7 \% \\
\text { expecting } \\
\text { enough the } \\
\text { adequate } \\
\text { number of } \\
\text { teachers }\end{array}$ & $\begin{array}{l}53.2 \% \\
\text { expecting } \\
\text { enough } \\
\text { the } \\
\text { adequate } \\
\text { number of } \\
\text { class }\end{array}$ & $\begin{array}{l}52.3 \% \\
\text { expectin } \\
\text { g very } \\
\text { much the } \\
\text { even } \\
\text { distributi } \\
\text { on }\end{array}$ & $\begin{array}{l}53.2 \% \\
\text { expecting } \\
\text { enough } \\
\text { the } \\
\text { easiness }\end{array}$ \\
\hline Assessment & $\begin{array}{l}66.7 \% \\
\text { fairly } \\
\text { compatible } \\
\text { to K13 }\end{array}$ & $\begin{array}{l}67.6 \% \\
\text { fairly } \\
\text { compatibl } \\
\text { e to K13 }\end{array}$ & $\begin{array}{l}73 \% \\
\text { fairly } \\
\text { compatib } \\
\text { le to K13 }\end{array}$ & $\begin{array}{l}63.1 \% \\
\text { supporting } \\
\text { enough }\end{array}$ & $\begin{array}{l}66.7 \% \\
\text { supportin } \\
\text { g enough }\end{array}$ & $\begin{array}{l}58.6 \% \\
\text { supporti } \\
\text { ng } \\
\text { enough }\end{array}$ & $\begin{array}{l}64.9 \% \\
\text { supportin } \\
\text { g enough }\end{array}$ \\
\hline
\end{tabular}

From the table, it can be seen the result of calculation for frequency distribution of students' perception entirely, as shown in the table 3.

Table 3. Frequency distribution of students'variable perception

\begin{tabular}{|l|l|l|l|}
\hline Category & Interval & Frequency & Percentage \\
\hline Positive & $66-83$ & 63 & $56.76 \%$ \\
\hline Negative & $48-65$ & 48 & $43.24 \%$ \\
\hline Total & $\mathbf{1 1 1}$ & $\mathbf{1 0 0 \%}$ \\
\hline
\end{tabular}

The table shows that out of 111 respondents, $56.76 \%$ or 63 respondents have response score interval of 66 - 83 belonging to positive perception category. It means that students know the cross-major implementation at school, students expect that the cross-major implementation at school can be adjusted with the rule of 2013 curriculum, and students view the cross-major implementation in school fairly compatible to the rule of 2013 curriculum. Meanwhile, $43.24 \%$ or 48 respondents have response score interval of 48 - 65 belonging to negative perception category. It means that students do not know the crossmajor implementation at school, students do not expect the cross-major implementation at school to be adjusted with the rule of 2013 curriculum, and students view the cross-major implementation at school incompatible to the rule of 2013 curriculum. 
Although, generally students have positive perception on the cross-major implementation at school, but there is difference of students' perception on cross-major subject implementation. Quantitative data states that most students (66.7\%) view cross-major subject selection system "fairly compatible" to the rule of 2013 curriculum, meaning that the students choose the subject freely according to their interest. Meanwhile, qualitative data states that cross-major subject selection system "incompatible" to the rule of 2013 Curriculum because it is decided based on school's decision and class agreement. It is in line with the previous study finding that students are not given right to decide their choice related to cross-major subject, because it has been specified by school (Dewi, 2016).

From the elaboration above, it can be found that most students cannot assess the compatibility of cross-major subject selection system between the rule in school and the rule of 2013 curriculum. It is due to two factors: (1) internal factor including students' knowledge related to cross-major rule in the 2013 curriculum, (2) external factor including school socializing only the rule it has modified, so that students consider that the rule is the actual rule of 2013 curriculum. In this condition, it can be seen that the agent evidently can modify the system so that actor accept it without resistance.

\section{DISCUSSION AND CONCLUSIONS}

A social system always attempts to adapt, to achieve objective, to integrate, and to maintain pattern to achieve equilibrium in order to survive in dealing with some change. Agent and actor adapt themselves to need and environment to achieve an objective through integration process by internalizing value and norm approved collectively in a long period of time. In this case, the cross-major implementation is conducted through modifying original rule into a new one corresponding to the schools' capability. The rule is developed recalling teacher availability, classroom, and even distribution of student number, and subject scheduling. Despite its incompatibility to the original rule, the modification of system successfully affects the actors, particularly students. The result of survey shows that out of 111 respondents, $56.7 \%$ or 63 respondents have positive perception.

The cross-major implementation existing in this school portrait the similar case in most schools in Indonesia. The reality related to limited human resource and spatial facility existing in school is not taken into account actually by the Government in issuing a new policy. Eventually, the objective of curriculum cannot be achieved maximally by the students. Social system existing in school does not give the students discretion. Meanwhile, the rationalization of the objective of curriculum and learning process should be oriented to the improvement of students' capability. School should cater and emphasize on students' need (T. Parsons \& Halsey, 2007). In this condition, a valuable lesson can be taken, i.e. the importance of bottomup policy formulation. Unfortunately, in Indonesian education system and structure, this discretion has not been given fully to each of educational units.

Educational standardization paradigm still becomes government's main reference. Nevertheless, the mission of standardization existing is still defined as absolute uniformity. As a result, there is a gap between regulation and the reality. Standardization should be defined as education development and building to achieve the same mission according to the characteristic and capability of individual schools. The condition is most likely applied recalling varying economic distribution, development, and social-cultural condition in Indonesia.

Building education quality in Indonesia is not easy. Nonetheless, it should be endeavored together by government and society. In the future, perhaps Indonesian curriculum can change continuously with a label of mission to improve education quality. Unfortunately, an excuse of building education through the change of curriculum does not always run well. There is an indication that the policy is issued immaturely. It can be seen from this research's finding and the application of 2013 curriculum that has been revised several times. There are curriculum of 2013, revision edition of 2013 curriculum, and addition in 2018. In other condition, in fact, the result of evaluation on students' quality with PISA does not show significant improvement, even there is a tendency of decrease (Yulaningsih \& Aminah, 2014)(OECD, 2018)(OECD (2019), 2019b)(OECD (2019), 2019c)(OECD (2019), 2019a).

On theoretical implication level, it is this condition that becomes a gap in structural functional theory. The open space enabling the exchange to achieve system equilibrium is not taken into account as an indicator important to discuss. The equilibrium system concerns not only rule enforcement and control, but also discretion to give and accept. Building system equilibrium by considering the existing potency seems to be a solution needing to be considered by the adherents of structural functional theory. 


\section{REFERENCES}

Ahmad, I., Ur Rehman, K., Ali, A., Khan, I., \& Khan, F. A. (2014). Critical Analysis of the Problems of Education in Pakistan: Possible Solutions. International Journal of Evaluation and Research in Education (IJERE), 3(2), 79-84. https://doi.org/10.11591/ijere.v3i2.1805

Auliani, P., Nurdin, S., \& Bustaman, N. (2017). Pelaksanaan Layanan Peminatan Dalam Implementasi Kurikulum 2013. Jurnal Ilmiah Mahasiswa Bimbingan Konseling, 2(3), 92-99.

Azka, N. Mi. (2015). Problematika Penerapan Kurikulum 2013 pada Pembelajaran Lintas Minat Kimia di Kelas X Ilmu-Ilmu Sosial (IIS) MAN Kota Tegal.

Burhanudin, T. (2016, September). Malang Singkirkan Yogyakarta Sebagai Kota Pendidikan. Marketing.Co.Id.

Chairunnisa. (2011). Persepsi Siswa Terhadap Metode Pembelajaran Guru Dan Hasil Belajar Bahasa Indonesia Di Smk Al-Hidayah Ciputat.

Creswell. (2015). Riset Pendidikan: Perencanaan, Pelaksanaan, dan Evaluasi Riset Kualitatif \& Kuantitatif (Kelima). Pustaka Belajar.

Dewi, R. P. R. (2016). Strategi Adaptasi Siswa Lintas Minat MIPA dalam Pembelajaran Sosiologi (Studi Kasus SMAN 6 Semarang).

Direktorat Jenderal Pendidikan Dasar dan Menengah Kementerian Pendidikan dan Kebudayaan. (2017). Model Peminatan dan Lintas Minat.

Giddens, A. (1993). New Rules of Sociological Method. In Polity Press (2nd ed.).

Khotimah, K. (2019). Implementasi Kurikulum 2013 di SMA Islam Al Azhar 9 Yogyakarta. Jurnal Manajemen Pendidikan Islam, 1(2), 90-108.

Kinseng, R. A. (2017). Strukturgensi : Sebuah Teori Tindakan. Jurnal Sosiologi Pedesaan, 127-137.

Kotler, P. (2000). Marketing Management: Analysis, Planning, Implementation and Control (8th ed.). Prentice Hall International Inc.

Machali, I. (2014). Kebijakan Perubahan Kurikulum 2013 dalam Menyongsong Indonesia Emas Tahun 2045. Jurnal Pendidikan Islam, 3(1), 71-93. https://doi.org/10.14421/jpi.2014.31.71-94

Maunah, B. (2016). Pendidikan Dalam Perspektif Struktural Konflik. CENDEKIA: Journal of Education and Teaching, 10(2), 159-178. https://doi.org/10.30957/cendekia.v9i1.53

Melmambessy, R. (2017). Pelaksanaan Proses Peminatan Berdasarkan Implementasi Kurikulum 2013 Terhadap Tingkat Kepuasan Peserta Didik. Jurnal Bimbingan Dan Konseling Terapan, 1(1), 8.

Moleong, L. J. (2016). Metodologi Penelitian Kualitatif (Revisi). PT Remaja Rosdakarya.

Mulyasa, E. (2013). Pengembangan dan Implementasi Kurikulum 2013. Remaja Rosdakarya.

Musdar. (2015). Persepsi Siswa Kelas XI IPA dan XII IPS terhadap Peminatan dan Lintas Minat Kurikulum 2013 di Sekolah Menengah Atas Negeri 4 Banda Aceh. Jurnal Fisika Edukasi, 2(1), 10-17.

Nirzalin. (2013). Mendamaikan Aktor dan Struktur dalam Analisis Sosial Perspektif Teori Strukturasi Antony Giddens. Jurnal Sosiologi Universitas Syiah Kuala (Media Pemikiran \& Aplikasi), 3(3), 15-24. https://doi.org/10.24815/jsu

Noer, R. (2016). Pelaksanaan Program Lintas Minat Sosiologi Pada Kurikulum 2013 (Studi Kasus Pada Siswa Kelas X MIPA di SMAN 1 Bulakamba Kabupaten Brebes Tahun Pelajaran 2015/2016). Universitas Negeri Semarang.

Nugroho, Y., \& Prishardoyo, B. (2017). Persepsi Siswa Kelas X MIPA tentang Pelaksanaan Peminatan dan Lintas Minat Ekonomi di SMA Negeri 1 Batang. Economic Education Analysis Journal, 6(1), 25-35.

OECD. (2018). What 15-year-old students in Indonesia know and can do. Programme for International Student Assessment (PISA) Result from PISA 2018, 1-10. http://www.oecd.org/pisa/ Data

OECD (2019). (2019a). Mathematics performance (PISA). https://doi.org/10.1787/79913c69-en

OECD (2019). (2019b). Reading performance (PISA) (indicator). https://doi.org/10.1787/79913c69-en

OECD (2019). (2019c). Science performance (PISA). https://doi.org/10.1787/91952204-en

Oliva, P. F., \& Gordon, W. R. (2013). Developing the Curriculum (8th ed.). Pearson.

Parsons, T., \& Halsey, A. H. (2007). The school class as a social system. Schools and Society: A Sociological Approach to Education.

Parsons, Talcott, \& Mayhew, L. H. (1982). On Institutions And Social Evolution. In The University of Chicago Press (1985th ed.).

Permana, R. W. (2016). Malang Sebagai Kota Pendidikan Sejak Masa Hindia Belanda. Merdeka.Com.

Riafadilah, A., \& Dewi, L. (2018). Evaluasi terhadap Implementasi Lintas Minat dalam Kelompok Peminatan di SMA/MA Kecamatan Lembang. Jurnal Penelitian Ilmu Pendidikan, 11(2), 128-133. https://doi.org/10.21831/jpipfip.v11i2.19831

Ritzer, G., \& Goodman, D. J. (2008). Teori Sosiologi: Dari Teori Sosiologi Klasik Sampai Perkembangan Mutakhir Teori Sosial Postmodern. Kreasi Wacana. 
Singarimbun, M., \& Effendi. (2006). Metode Penelitian Survei (18th ed.). Pustaka LP3ES.

Slameto. (2010). Belajar dan Faktor yang Mempengaruhinya. Rineka Cipta.

Sugiyono. (2011). Metode Penelitian Kualitatif, Kuantitatif, R\&D. Alfabeta.

Toha, M. (2003). Perilaku Organisasi Konsep Dasar dan Aplikasinya. Grafindo Persada.

Turner, H., J., \& Maryanski, A. (2010). Fungsionalisme (A. Efffendi (ed.)). Pustaka Pelajar.

Wahyudi, Ulfah, \& Ahmadi. (2018). Implementasi Pembelajaran Lintas Minat Mata Pelajaran Ekonomi Sains SMA Negeri 1 Sungai Ambawang. Jurnal Pendidikan Dan Pembelajaran Khatulistiwa, 7(7), 9.

Widianto, A. A., Gita Purwasih, J. H., \& Perguna, L. A. (2020). Promoting social cohesion: The development of elearning management system materials through life based learning for sociology of religion course. International Journal of Emerging Technologies in Learning, 15(7), 162-170. https://doi.org/10.3991/IJET.V15I07.13339

Widiawati, K. A. (2019). Pengelolaan Pembelajaran Kimia Peminatan dan Lintas Minat di Tingkat SMA. Jurnal Pendidikan Kimia Indonesia, 3(1), 24-31. https://doi.org/10.23887/jpk.v3i1.20945

Yulaningsih, \& Aminah, N. A. (2014). Literasi Indonesia Sangat Rendah | Republika Online. Republika. 